\title{
LETTER TO Rhinosinusitis invisible in the IPCRG THE EDITOR Research Needs Statement?
}

\section{*Wytske Fokkens ${ }^{a}$, on behalf of Dr J Mullul and Professor} $\checkmark$ Lund, the co-chairs of EP3OS

a Department of Otorhinolaryngology, Academic Medical Centre, Amsterdam, The Netherlands

${ }^{*}$ Correspondence:

Professor Wytske J Fokkens

Department of Otorhinolaryngology,

Academic Medical Centre,

Meibergdreef 9,

Amsterdam,

1100DD

The Netherlands

Tel: +3120566 3789

Fax: +31205669662

E-mail: w.j.fokkens@amc.nl

18th September 2010

C 2010 Primary Care Respiratory Society UK. All rights reserved

\section{Dear Sir,}

With great interest I read the PCRJ supplement 'The International Primary Care Respiratory Group (IPCRG) Research Needs Statement'1 published in June this year.

However, to my great disappointment, the word 'rhinosinusitis' was invisible in this research needs paper. We now have (still unpublished) data from the GA2LEN questionnaire confirming that rhinosinusitis affects $10-20 \%$ of the European population.

Only recently, you published our primary care-focussed summary of the EPOS Guidelines. ${ }^{2}$ In the summary of this paper we wrote:

"This paper is a summary of the 2007 European Position Paper on Rhinosinusitis and Nasal Polyps (EP3OS) which was published in Rhinology in 2007. In order to widen dissemination of the EP3OS paper, the editors of Rhinology and the Primary Care Respiratory Journal (PCRJ) have agreed to publish this summary - which is focussed on the needs of general practitioners and community-based non-specialist clinicians - in the PCRJ. In the EP3OS process, an evidence-based methodology was used to identify evidence and to grade recommendations for clinical practice for the management of rhinosinusitis. The EP3OS Taskforce was commissioned by the European Academy of Allergology and Clinical Immunology (EAACI) with the aims of:

- Presenting specialist and generalist clinicians with an updated summary of knowledge of rhinosinusitis and nasal polyposis

- Providing clinicians with an evidence-based summary of diagnostic methods appropriate for specialist and generalist settings

- Providing evidence-based recommendations for management in specialist and generalist settings

- Proposing guidance for definitions and outcome measurements in clinical practice and in research in different settings.

The current document aims to distil the information presented in the full EP3OS document into a shorter and more concise format suitable for use in primary care generalist settings. The summary recommendations for generalists are that clinicians should be aware that rhinitis and sinusitis usually co-exist, and that management strategies should encompass this."

Apparently, the latter has not been achieved yet. I hope that in any future Research Needs statement, 'rhinosinusitis' finds its place. If the EP3OS group or myself can be of any help, please let me know.

\section{Conflict of interest declaration}

None.

\section{References}

1. Pinnock H, Thomas M, Tsiligianni I et al. The International Primary Care Respiratory Group (IPCRG) Research Needs Statement 2010. Prim Care Resp J 2010;19(Suppl 1):S1-20. http://dx.doi.org/10.4104/pcrj.2010.00021

2. Thomas M, Yawn B, Price D, Lund V, Mullol J, Fokkens W. EPOS Primary Care Guidelines: European Position Paper on the Primary Care Diagnosis and Management of Rhinosinusitis and Nasal Polyps 2007 - a summary. Prim Care Resp J 2008;17(2):79-89. http://dx.doi.org/10.3132/pcrj.2008.00029 


\section{Authors' reply}

We thank Professor Fokkens and her colleagues for their interest ${ }^{1}$ in the International Primary Care Respiratory Society (IPCRG) Research Needs Statement, ${ }^{2}$ and fully concur with the aim of the European Position Paper on Rhinosinusitis and Nasal Polyps to raise the profile of rhinosinusitis amongst generalist clinicians. ${ }^{3}$ Although it is very frequently encountered, this condition is widely unrecognised and under-diagnosed potentially leading to inappropriate treatment. We also agree that rhinosinusitis is an area which requires further research within the primary care arena. $^{3}$

However, the primary focus of the IPCRG Research Needs Statement was the three common lung conditions (asthma, COPD and lower respiratory tract infections), along with two important related conditions (nicotine dependence and nasal allergy). For this reason we concentrated on allergic rhinitis rather than rhinosinusitis, a maladaptive response to infection. This does not deny the importance of rhinosinusitis, but merely reflects the need for focus within the confines of a word-limited document. For similar reasons, the Research Needs Statement also specifically excluded discussion of upper respiratory tract infections.

Recent publications in the Primary Care Respiratory Journal provide evidence of the increasing importance attached by respiratory-interested primary care professionals to the challenge of raising the profile of this all too prevalent problem. ${ }^{3-5}$ It may be that future iterations of the IPCRG statement will extend the focus to include a discussion of the research needs related to rhinosinusitis.

\section{References}

1. Fokkens W. Rhinosinusitis invisible in the IPCRG Research Needs Statement? Letter. Prim Care Resp J 2010;19(4):403-04. http://dx.doi.org/10.4104/pcrj.2010.00074

2. Pinnock H, Thomas M, Tsiligianni I et al. The International Primary Care Respiratory Group (IPCRG) Research Needs Statement 2010. Prim Care Resp J 2010;19(Suppl 1):S1-20. http://dx.doi.org/10.4104/pcrj.2010.00021

3. Thomas M, Yawn B, Price D, Lund V, Mullol J, Fokkens W. EPOS Primary Care Guidelines: European Position Paper on the Primary Care Diagnosis and Management of Rhinosinusitis and Nasal Polyps 2007 - a summary. Prim Care Resp J 2008;17:79-89. http://dx.doi.org/10.3132/pcrj.2008.00029

4. Ryan D. Management of acute rhinosinusitis in primary care: changing paradigms and the emerging role of intranasal corticosteroids Prim Care Resp J 2008;17:148-55. http://dx.doi.org/10.3132/pcrj.2008.00050

5. Hansen JG. The effect of acute rhinosinusitis on pulmonary function in adults. Prim Care Resp J 2009;18:224-6. http://dx.doi.org/10.3132/pcrj.2000.00005

\section{Dermot Ryan ${ }^{\mathrm{a}}$, Osman Yusuf ${ }^{\mathrm{b}},{ }^{*}$ Hilary Pinnock ${ }^{\mathrm{c}}$}

a General Practitioner, Woodbrook Medical Centre, Loughborough, UK

b Chief Primary Care/GP Trainer, and Consultant Allergy and Asthma Specialist, The Allergy \& Asthma Institute, Islamabad, Pakistan

c Senior Clinical Research Fellow, Allergy and Respiratory Research Group, Centre for Population Health Sciences: GP Section, University of Edinburgh, Scotland, UK

*Correspondence:

Dr Hilary Pinnock

Allergy and Respiratory Research Group, Centre for Population Health Sciences: GP Section, University of Edinburgh, Doorway 3, Medical School, Teviot Place, Edinburgh EH8 9AG, Scotland, UK

Tel: +44 (0)1316508102 Fax: +44 (0)1316509119

E-mail: hilary.pinnock@ed.ac.uk

doi:10.4104/pcrj.2010.00073

\section{Available online at http://www.thepcrj.org}

